\title{
Gender Issues and Women's Agency in Involuntary Resettlement: The Tokuyama Dam in Japan
}

\author{
Shuichi Yamazawa (Corresponding author) \\ Graduate School of Frontier Sciences, The University of Tokyo \\ 5-1-5 Kashiwano-ha, Kashiwa, Chiba, 277-8561, Japan \\ Tel: 81-80-5495-2025_E-mail: shuichiyamazawa0728@gmail.com \\ Kanae Moriya \\ Graduate School of Frontier Sciences, The University of Tokyo \\ 5-1-5 Kashiwano-ha, Kashiwa, Chiba, 277-8561, Japan \\ Tel: 81-90-8651-9471_E-mail: kanaemoriya22@gmail.com
}

Received: January 10, 2019 Accepted: January 29, 2019 Published: February 28, 2019

doi:10.5296/jad.v5i1.14424 URL: https://doi.org/10.5296/jad.v5i1.14424

\begin{abstract}
This research evaluates the Tokuyama dam resettlement in Japan through the short-term from a gender perspective using the IRR and PAR models. Moreover, this research also evaluates the resettlement and clarifies the changes in women's jobs in the long-term. As for short-term evaluation, the risks that women faced during the negotiation period and after resettlement are categorized into three issues: landlessness, joblessness, and loss of access to common property assets. Women have tried to solve these issues with agency, although they are usually recognized as passive victims in the context of forced displacement. In addition, the attitudes of "dam brides"- those who married men originally from Tokuyama in the period immediately prior to the dam construction and subsequent resettlement-were different from women originally from Tokuyama village. As for the long-term evaluation, changes of women's productive activities are mainly categorized into three patterns: part-time jobs, sewing jobs as side work, and farming.
\end{abstract}

Keywords: resettlement, compensation, livelihood, gender 


\section{Introduction}

\subsection{Gender Issues of Involuntary Resettlement}

The number of involuntary resettlements by development projects has increased substantially through the last two decades. The number of projects triggering the involuntary resettlement policy by the World Bank's projects has grown from 146 active projects in 1993 to 747 active projects as of December 2009, representing 29\% of the portfolio (World Bank, Environmentally Sustainable Department, 1996; World Bank, 2012). In addition, gender issues caused by displacement were also reported. Gender issues have been observed in several Asian dam construction projects. In the case of the Three Gorges Project in China, women were unable to get a new occupation after relocation due to discrimination against women and a lack of education (Tan, Hugo, \& Potter, 2005). In the case of the Bakun Hydro-Electric Project in Malaysia, the wives had no choice but to stay home, although their husbands went to the cities to earn money. Therefore, the wives faced challenges in caring for their families, in addition to securing food by planting crops. Moreover, women lost access to natural resources that provided food and craft materials in their original villages (Jehom, 2013). In the case of the Mahaweli Project in Sri Lanka, women were excluded from the right to own lands and their burden increased after resettlement because of the introduction of double cropping (Kumar, 1987). In the case of the Sardar Sarovar dam in India, a lack of water infrastructure in the resettlement area created particular problems for women. For example, women have to leave home to defecate outside before dawn or after dark because it is culturally unacceptable to be seen defecating (Sikka, 2016). These researchers suggest that gender differences were overlooked in the resettlement and livelihood reestablishment processes and that resettlement tends to exacerbate gender disparities that exist in project-affected areas.

On the other hand, in Japan, there were many cases where those who were transferred by involuntary resettlement were unable to rebuild their lives and, so, became impoverished. According to the Japan Dam Foundation (2016), hundreds of dams were constructed in Japan for agriculture, electricity generation, and disaster prevention during the rapid economic growth period after World War II. However, the number of gender studies is restricted within the context of dam construction in Japan. When we researched the cases of the Tokuyama dam in Japan from the view point of gender, it became clear that there were "dam brides" who married men who were originally from Tokuyama in the period immediately prior to the dam construction and subsequent resettlement (Yamazawa, Moriya, \& Nakayama, 2018). These women knew that the men would secure hefty compensation by leaving their homes in the old Tokuyama village. The women mostly met men from Tokuyama village in cities where the men worked as seasonal workers in the winter. Another case is that some of "dam brides" were married to men who could not inherit land to prevent land fragmentation and started working in big cities. These "dam brides" build a new house in Tokuyama village with husband who originally did not inherit a land and they started to live in Tokuyama village and made a new independent household in Tokuyama to get compensation. In addition, it became clear that a "dam bride" had five completely different characteristics from a woman originally from Tokuyama village: 
1. "Dam brides" strongly agreed with resettlement and stayed in Tokuyama for the short term.

2. "Dam brides" were not satisfied with the infrastructure in the resettled areas, which was inferior to that in their hometown.

3. "Dam brides" tended to find new occupations without difficulty after resettlement.

4. "Dam brides" experienced more difficulties in establishing good relationships with their mothers-in-law than the wives coming from old Tokuyama village due to cultural differences between Tokuyama and big cities.

5. "Dam brides" generally had a good relationship with people in the host community through communal activities, whereas original Tokuyama villagers rarely interacted with those in the host community.

However, the studies about gender issues are not sufficient, although the latest research proved the existence of "dam brides." Accordingly, one of the purposes of this study is to clarify the presence of the gender issue within the context of involuntary resettlement due to dam construction in Japan.

\subsection{Women's Agency}

Gender issues are also present in the subject of resettlement by natural disaster. Chowdhury (2001) has pointed out that women have a high risk of being injured by natural disasters because they are usually in their homes, and men have a lower risk because they usually work outside a shoal zone. However, Bari (1992) has pointed out the important role of women who tackle the challenges of natural disasters with agency. Kabeer (1996) defined "agency" as the ability to define one's goals and act upon them. Such cases where women engage in reconstruction activities with agency after earthquake disasters have been documented in cases of earthquake disasters in Japan as well. Aoki (2017) examined records of the four major earthquakes from the Taisho period to the present (the Great Kanto Earthquake, Great Hanshin-Awaji Earthquake, Chuetsu Earthquake, and Great East Japan Earthquake). He noted that women provided supports in such major earthquakes. However, there are a few studies which indicate that women overcome gender issues within the context of resettlement due to dam construction, while women's important role engaging in reconstruction activities with agency are pointed out in disaster cases. Therefore, one of the purposes of this research is to elucidate how women overcame gender issues which have been insufficiently studied and arise by involuntary resettlement in dam construction in Japan.

\subsection{Long-Term Impacts for Women}

Scudder (2005) researched more than 50 cases of resettlement by dam construction and created the Four Stage Framework model. This model categorizes resettlement into four processes: 1. Recruitment Stage, 2. Transition Stage, 3. Stage of Potential Development, and 4. Handing Over/Incorporation Stage. As shown by Scudder's model, resettlement by dam construction has to be evaluated in both the short and long term. In the Tokyuyama dam case in Japan, Kimura (1997) conducted follow-up surveys for more than 30 years of the resettlement process, from the period of negotiation until after resettlement, and identified the 
changes observed in Tokuyama. Hamamoto (2001) found that people from Tokuyama suffered from emotional distress in three periods: a negotiation period, a livelihood reestablishment period, and a period of movement against dam construction in another city, which made displaced people think that dam construction is useless. However, only monetary issues were discussed in the process of negotiating the resettlement.

On the other hand, some researchers evaluated the long-term consequences of resettlement. Nakayama and Matsumoto (2016) analyzed the cases of the Tokuyama dam and the Miboro dam. They pointed out that these dams were developed in an era of very rapid economic growth in Japan and that, prior to the resettlement, the displaced persons had mostly been engaged in farming and forestry, without specific skills to secure new occupations after resettlement in urban areas. The authors also suggested that land-for-land compensation may not be the best option for resettlers because many of them wanted to relocate to urban areas and abandon farming as their major source of income. Sugiura and Matsumoto (2016) compared the Tokuyama case with the Kusaki and Sameura dams. They showed the pattern of resettlement after displacement, which correlates with the degree of dependency on the productivity of the farm land.

However, such studies are basically interview researches subject to the male head of a household; as such, long-term resettlement has not yet been evaluated in terms of gender. Thus, in this research we evaluate resettlement because of dam construction in Japan in terms of gender issues in the long term. Table 1 is a summary of previous studies. In this Table1, tick means that the research in the field is relatively sufficient and cross means that the resaerch in the field is not sufficient. Also, we focus on women's activities from which we can observe the long-term transition when we evaluate long-term resettlement in terms of gender. Tanaka (2002) categorized three types of activities: 1. productive, 2. reproductive , and 3. community activity. Productive activities include farming, livestock, and wage labor. Reproductive activities include cooking, washing, and fetching water. And community activities include group work in village and ceremonial occasions. In this research, we focus on productive activities, as the long-term transition is easy to observe among these activities.

In summary, the research questions in this study are the following:

1) What kind of gender issues did women face after resettlement?

2) How did women overcome gender issues with agency?

3) What kind of productive activities have women been engaged in through the long term? 
Table 1. The Summary of Previous Studies

\begin{tabular}{|c|c|c|c|c|c|c|c|}
\hline \multirow{2}{*}{$\begin{array}{l}\text { Cause } \\
\text { perspective }\end{array}$} & \multicolumn{5}{|c|}{ Dam Resettlement } & \multicolumn{2}{|c|}{ Natural Disaster } \\
\hline & general & & gender & & & gender & \\
\hline category & $\begin{array}{l}\text { short } \\
\text { term } \\
\text { impact }\end{array}$ & $\begin{array}{l}\text { long } \\
\text { term } \\
\text { impact }\end{array}$ & $\begin{array}{l}\text { short } \\
\text { term } \\
\text { impact }\end{array}$ & $\begin{array}{l}\text { long } \\
\text { term } \\
\text { impact }\end{array}$ & $\begin{array}{l}\text { women's } \\
\text { agency }\end{array}$ & $\begin{array}{l}\text { short } \\
\text { term } \\
\text { impact }\end{array}$ & women's agency \\
\hline Japan & $\checkmark$ & $\checkmark$ & $\boldsymbol{x}$ & $\boldsymbol{x}$ & $\boldsymbol{x}$ & $\checkmark$ & $\checkmark$ \\
\hline $\begin{array}{l}\text { other } \\
\text { countries }\end{array}$ & $\checkmark$ & $\checkmark$ & $\checkmark$ & $\boldsymbol{x}$ & $\boldsymbol{x}$ & $\checkmark$ & $\checkmark$ \\
\hline
\end{tabular}

: Research in the field is relatively sufficient.

$\boldsymbol{*}$ : Resaerch in the field is not sufficient.

\section{Methodology}

We carried out surveys in September 2018. We interviewed six women who resettled due to the Tokuyama dam construction. Our interviewees included women originally from Tokuyama village and "dam brides" who were originally from outside of the village. The survey was undertaken in the resettlement areas of "Omoteyama," "Monjyu," and "Shibahara" under the condition that interviewees would be kept anonymous.

In order to clarify the gender issues in the dam resettlement context and identify how women overcome difficulties, the Impoverishment Risks and Reconstruction model (IRR model) and Pressure and Release model (PAR model) will be used. The IRR model by Cernea (2000) categorizes the factors connected to the impoverishment of resettlers into eight risks: 1 . landlessness, 2. joblessness, 3. homelessness, 4. marginalization, 5. morbidity, 6. food insecurity, 7. loss of access to common property assets, and 8. social disarticulation. This model is the basic theory for development agencies currently. A questionnaire was made based on the eight risks in the IRR model. Therefore, this research will clarify which risks women faced during the negotiation period.

The PAR model analyzes the factors connected to a disaster (Figure 1). This model explains that a disaster is caused by not only hazards such as earthquakes and flooding, but also the victims' vulnerability. Vulnerability is categorized into three types: root causes, dynamic pressures, and unsafe conditions. Root causes refers to a lack of "access" to power, structure, and resources, and "ideologies" of political and economical systems. Dynamic pressures can be categorized into micro and macro-levels. Factors connected to vulnerability at the micro-level include local institutions, local investment, local markets, and so on. Factors at the macro-level include rapid population change, rapid urbanization, deforestation, and so on. Unsafe conditions mean factors categorized within the physical environment (such as a dangerous location), local economy (such as low-income levels), social relations (such as special groups at risk), public actions and institutions (such as lack of preparedness). Usually, this model is applied to a natural disaster case; therefore, it has seldom been used for analyzing resettlement by development. However, a situation where society is damaged by 


\section{Macrothink Institute ${ }^{T M}$}

disaster and a society is affected by development seem to be similar because both societies become unstable; it was thus obvious that people became impoverished due to not only hazards by disaster or evacuation by development, but also because of their vulnerability. Therefore, the PAR model seems useful in analyzing vulnerability and it is possible to apply it to dam resettlement in this study. Moreover, not only failure factor but also success factor will be analyzed in this study since PAR model is also useful to describe the factors do not connect to disaster. As Wisner, B., Gaillard, J. C., \& Kelman, I. (2012) explained, policy and practice has sometimes strengthened livelihoods and made locations and conditions safer, confronted and countered dynamic pressures and, occasionally, even addressed some of the root causes of vulnerability.

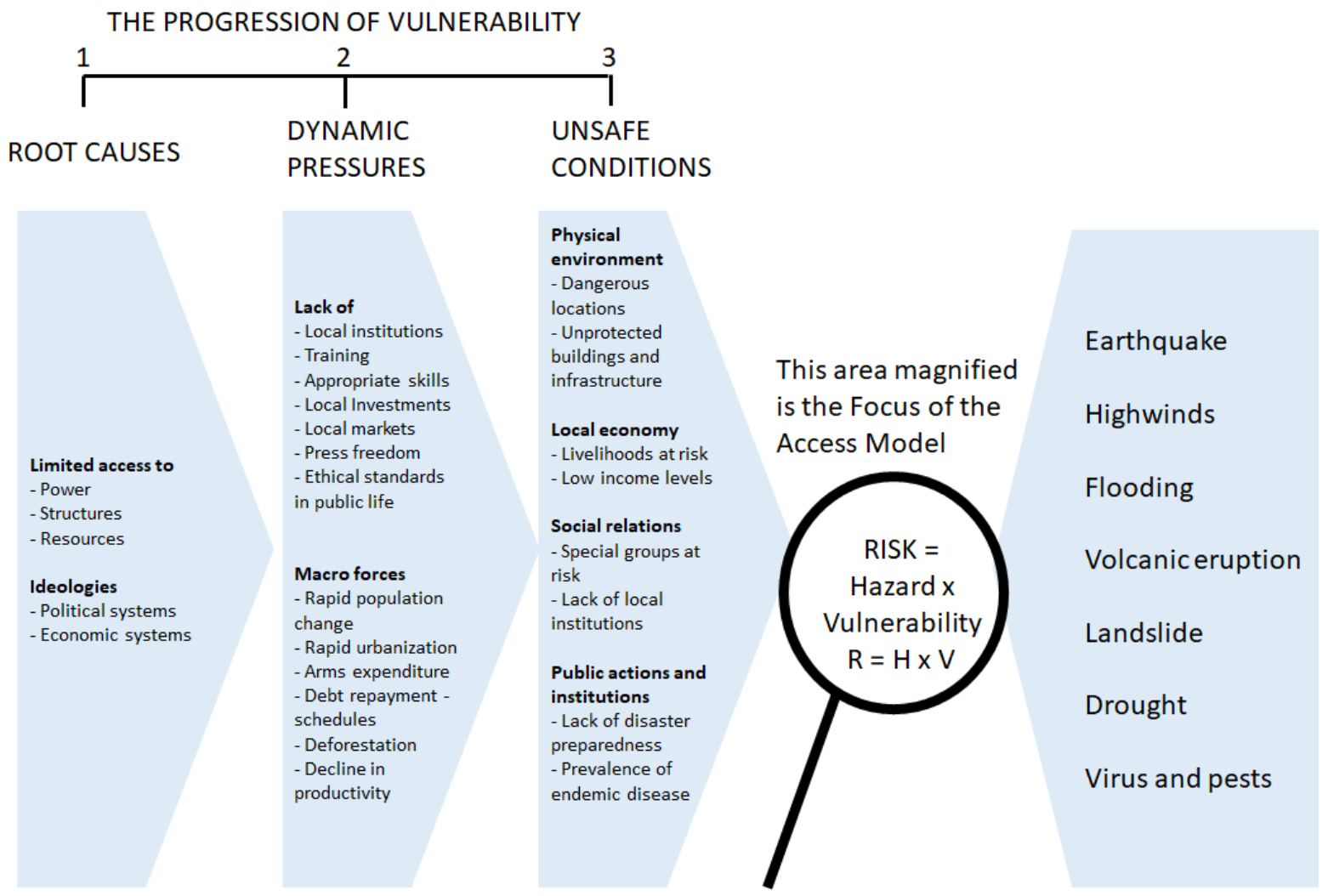

Figure 1. PAR model

Source: Blaikie, P., Cannon, T., Davis, I., \& Wisner, B. (2004)

\section{Tokuyama Dam Construction and Resettlement of Residents}

The Tokuyama dam in Gihu prefecture is the largest multipurpose dam in Japan. It has a water storage capacity of 660 million tons. The dam was built on the Ibi River for the purposes of power generation, flood management, and industrial water supply by the Japan Water Agency (JWA), owner of the dam. Figure 2 shows the location of the Tokuyama dam. A unique feature of the dam is that almost all lands in Tokuyama were submerged and all 466 households (about 1500 people) had to move. Table 2 shows a timeline of the Tokuyama dam 


\section{Macrothink}

construction. The JWA asked the resettlers either (a) to move to one of the five resettlement areas built by the JWA, or (b) to move to a place of their own choice. Tokuyama had been composed of eight hamlets. The villagers from these hamlets were "mixed" in the five resettlement areas of Omoteyama, Monjyu, Shibahara, Itonuki, and Amishiro, which were existing residential communities. The lifestyle of the resettlers completely changed after relocation. Before resettlement, villagers were mostly engaged in farming or forestry because the village was located deep in the mountain. After resettlement, about $40 \%$ of the family heads changed their occupation and about $60 \%$ of their spouses changed their occupation. The ratio of people engaging in farming or forestry dropped significantly from $25.8 \%$ to $3.6 \%$ (Gihuken chihou jichi kenkyuu senta, 1988).

Table 2. Timeline of the Tokuyama Dam Construction

\begin{tabular}{ll}
\hline Year & \multicolumn{1}{c}{ Event } \\
\hline 1957 & Proposal of the Tokuyama dam construction is first announced. \\
1976 & The plan of the Tokuyama dam construction is approved by the Ministry of Construction. \\
1984 & Resettlement begins. \\
1989 & All 466 households sign a contract with the Japan Water Agency. \\
2000 & The construction of the Tokuyama dam begins. \\
2008 & The Tokuyama dam construction is completed.
\end{tabular}

Source: Developed by the authors based on Fujihashi-mura (1990).

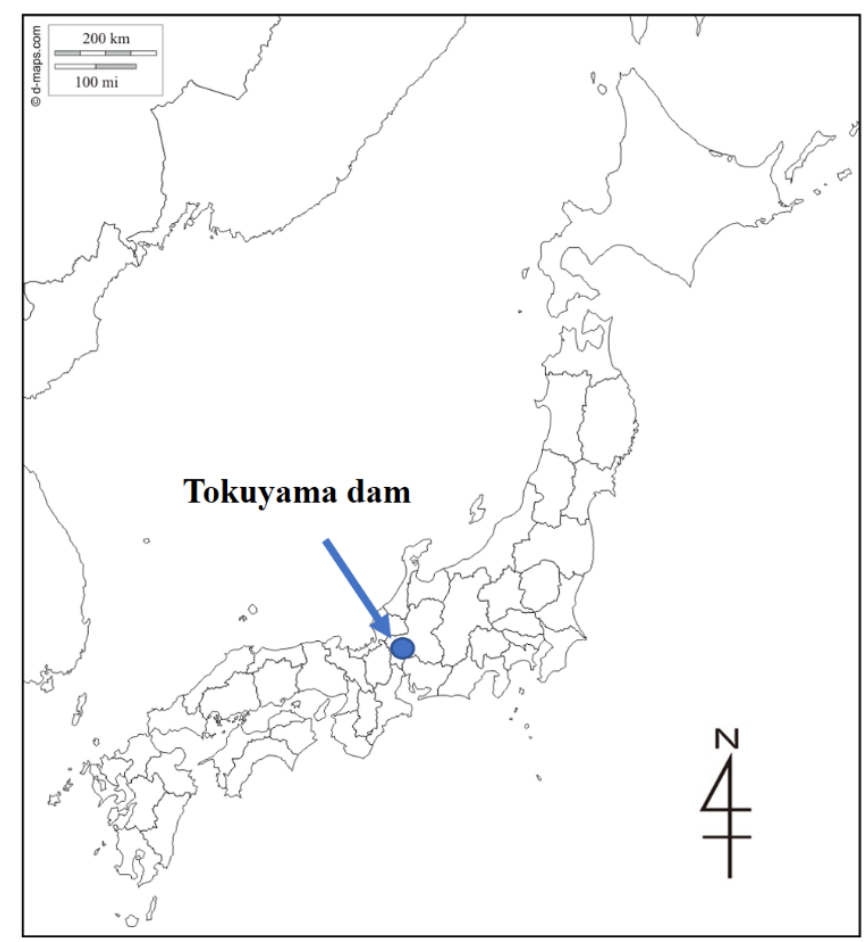

Figure 2. Location of the Tokuyama dam 


\section{Macrothink}

\section{Findings}

\subsection{Short-Term Impacts}

Based on the IRR model, the risks that women faced during the negotiation period and after resettlement are categorized into three issues: landlessness, joblessness, and loss of access to common property assets. These three issues will be analyzed based on the PAR model. Also, this analysis will clarify what kinds of factors are connected to success or failure of resolution by the women (see Table 3).

\subsubsection{Landlessness}

\section{(1) Women's participation}

During the negotiation period about resettlement, meetings took place periodically and discussed who was eligible for getting compensation and how much compensation was necessary. These meetings (including bus trips to resettlement areas beforehand) involved women, although women seldom attend meetings in their own hamlets in daily life. The reason why women attended these meetings is that they received a daily allowance after each one and that there was a system which enabled them to attend. Therefore, when the husband was busy and the content of discussion seemed to be not complex, he forced the bride to attend the meeting. Although women had the opportunity to attend meetings, they did not voice their own opinions. The reason why women completely gave up expressing their opinions was due to cultural constraints; this can be explained as a root cause in the PAR model. However, it is important to point out that there was a system that allowed women to participate in meetings, and which can be understood as dynamic pressure (at the micro-level) within the PAR model.

(2) Decrease of farm lands

Women always had to be engaged in all processes of farming in Tokuyama as this was their role. However, after resettlement, most Tokuyama villagers could not get farm land and, thus, women did not have to cultivate it anymore. Therefore, the women's burden dramatically decreased and they became part-time workers. There are two factors as to why they did not receive farm lands. First, there was a system that gave resettlers an option as to whether they could continue farming or not and which can be explained as dynamic pressure (micro-level). Second, an acreage-reduction policy was implemented by the government at that time; this can be explained as dynamic pressure (macro-level).

\subsubsection{Joblessness}

(1) Job opportunity

An acreage-reduction policy, which intended to reduce rice production, was implemented due to excess amount of rice production in Japan at that time. Therefore, it was necessary for resettlers to find new jobs other than farming (this can be explained by dynamic pressure at the macro-level). However, at that time, due mainly to rapid economic growth in Japan, there were enough job opportunities and even women coming from rural areas found work such as 
sewing (this can be categorized as dynamic pressure at the macro-level). Therefore, women were engaged in not only part-time work, but also sewing jobs in their houses while doing other house work such as child-raising. Another reason why women found new work easily is that a system of job placement in the resettlement scheme enabled them to, for example, obtain cooking licenses (an instance of dynamic pressure at the micro-level). Moreover, dam brides already had experience in working part-time in big cities. Therefore, these experiences became one of the factors that helped them to easily start part-time work and earn their own money (an example explained by root causes).

\section{(2) Funding}

After displacement by development or natural disasters, microfinancing for women was sometimes introduced. In cases of displacement by dam construction in Japan, some prefectures that benefited from the construction created a fund to facilitate reestablishing the livelihood of the resettlers. As for the Tokuyama dam construction, a fund called "zaidan hojin kiso sansen suigen chiiki taisaku kikin" was made for the resettlers. One of the benefits that resettlers received from this fund is money distribution. Five million yen for each household was distributed for livelihood reestablishment. Although it was not prepared specifically for women's empowerment, it was possible for women to use this money to find new roles. However, it became clear that all the women who were interviewed in this research did not know about the money distribution and only their husbands used the money for such things as their hobbies. The reason why women did not know about the money distribution stemmed from the relationship between wife and husband. In Tokuyama, the husband always manages the money and the wife does not have the right to do so (an example that can be explained by root causes in the PAR model).

\subsubsection{Loss of Access to Common Property Assets}

Sometimes women participated in the inspection process by the JWA to define which area of the common forest is owned by each household. Women had an opportunity to attend negotiations regarding the common forest due to a system of daily allowance for the participants (an example of dynamic pressure at the micro-level in the PAR model). However, there was a slight difference between dam brides and Tokuyama women: one dam bride said that Tokuyama villagers were more familiar with the common forest than outsiders and that is why Tokuyama women strongly insist on their right to own the common forest (an instance of root causes in the PAR model) (Anonymous, 2018a). 
Table 3. Results of Analysis by PAR model

\begin{tabular}{|c|c|c|c|c|c|c|}
\hline Category & $\begin{array}{l}\text { Gender } \\
\text { Issue }\end{array}$ & $\begin{array}{l}\text { Type of } \\
\text { Factor }\end{array}$ & Root Cause & $\begin{array}{l}\text { Dynamic Pressure } \\
\text { (macro) }\end{array}$ & $\begin{array}{l}\text { Dynamic Pressure } \\
\text { (micro) }\end{array}$ & $\begin{array}{l}\text { Unsafe } \\
\text { Condition }\end{array}$ \\
\hline \multirow{3}{*}{ Landlessness } & \multirow{2}{*}{$\begin{array}{l}\text { Women's } \\
\text { opinion }\end{array}$} & $\begin{array}{l}\text { Success } \\
\text { factor }\end{array}$ & & & $\begin{array}{l}\text { There was a } \\
\text { system of daily } \\
\text { allowance for } \\
\text { participants. } \\
\text { Therefore, women } \\
\text { had opportunities } \\
\text { to attend the } \\
\text { meeting. }\end{array}$ & \\
\hline & & $\begin{array}{l}\text { Failure } \\
\text { factor }\end{array}$ & $\begin{array}{l}\text { Women } \\
\text { completely } \\
\text { gave up } \\
\text { insisting on } \\
\text { their opinions } \\
\text { due to cultural } \\
\text { constraint. }\end{array}$ & & & \\
\hline & $\begin{array}{l}\text { Decrease of } \\
\text { farm land }\end{array}$ & $\begin{array}{l}\text { Success } \\
\text { factor }\end{array}$ & & $\begin{array}{l}\text { An } \\
\text { acreage-reduction } \\
\text { policy was } \\
\text { implemented by } \\
\text { the government. }\end{array}$ & $\begin{array}{l}\text { There was a } \\
\text { system where } \\
\text { resettlers had an } \\
\text { option whether } \\
\text { they could } \\
\begin{array}{l}\text { continue farming } \\
\text { or not. }\end{array}\end{array}$ & \\
\hline \multirow{3}{*}{ Joblessness } & \multirow[b]{2}{*}{$\begin{array}{l}\text { Women's } \\
\text { new role }\end{array}$} & \multirow[b]{2}{*}{$\begin{array}{l}\text { Success } \\
\text { factor }\end{array}$} & \multirow{2}{*}{$\begin{array}{l}\text { Dam brides } \\
\text { had } \\
\text { experiences in } \\
\text { working } \\
\text { part-time in } \\
\text { big cities. }\end{array}$} & $\begin{array}{l}\text { There were many } \\
\text { job opportunities } \\
\text { due to rapid } \\
\text { economic growth. }\end{array}$ & \multirow{2}{*}{$\begin{array}{l}\text { There was a } \\
\text { system of job } \\
\text { placement } \\
\text { due to obligation } \\
\text { for the constructor } \\
\text { to facilitate } \\
\text { livelihood } \\
\text { reestablishment. }\end{array}$} & \\
\hline & & & & $\begin{array}{l}\text { Necessity to find a } \\
\text { new job instead of } \\
\text { farming } \\
\text { due to an } \\
\text { acreage- reduction } \\
\text { policy. }\end{array}$ & & \\
\hline & Funding & $\begin{array}{l}\text { Failure } \\
\text { factor }\end{array}$ & $\begin{array}{l}\text { Women were } \\
\text { not aware of } \\
\text { the distribution } \\
\text { fund } \\
\text { due to men's } \\
\text { management } \\
\text { of money. }\end{array}$ & & & \\
\hline
\end{tabular}




\section{Ml Macrothink}

\begin{tabular}{|c|c|c|c|c|}
\hline \multirow[b]{2}{*}{$\begin{array}{l}\text { Common } \\
\text { property } \\
\text { assets }\end{array}$} & \multirow[b]{2}{*}{$\begin{array}{l}\text { Women's } \\
\text { participation }\end{array}$} & $\begin{array}{l}\text { Success } \\
\text { factor }\end{array}$ & & $\begin{array}{l}\text { Women had an } \\
\text { opportunity to } \\
\text { attend } \\
\text { negotiations } \\
\text { regarding the } \\
\text { common forest } \\
\text { due to a } \\
\text { system of daily } \\
\text { allowance for } \\
\text { participants. }\end{array}$ \\
\hline & & $\begin{array}{l}\text { Failure } \\
\text { factor }\end{array}$ & $\begin{array}{l}\text { Dam brides } \\
\text { faced a } \\
\text { problem of } \\
\text { lack of } \\
\text { knowledge due } \\
\text { to dam bride's } \\
\text { completely } \\
\text { different } \\
\text { background } \\
\text { from } \\
\text { Tokuyama } \\
\text { women. }\end{array}$ & \\
\hline
\end{tabular}

\subsection{Long-Term Impacts}

It became clear that women changed their productive activities in the long run after resettlement. Mainly, women's roles changed in three areas. Figure 3 shows the changes of women's productive activities before and after resettlement.

\subsubsection{Part-Time Jobs}

As mentioned before, women easily obtained part-time work after resettlement due to economic growth. However, most of them did not continue in these jobs until retirement age. Before women reached retirement, the husbands retired from their jobs and started new activities, such as small businesses, caring for their parents, and so on. Therefore, most of the women quit their jobs and started supporting their families.

\subsubsection{Side Jobs}

As also mentioned earlier, some of the women were engaged in side work (such as sewing) after resettlement. However, such job opportunities decreased because of economic stagnation. Therefore, women had no choice but to leave such work in the long run.

\subsubsection{Farming}

After resettlement, a very small number of women continued farming. As time passed, these women who continued farming asked their husbands to buy farming machinery; they also borrowed machines from the Japan Agricultural Co-operatives (JA). Therefore, women in 
this case did not face gender issues of women's burden as in other cases. However, as these resettlers aged, they lent farm land free of charge because the second generation did not want to inherit this land or to be engaged in farming. In addition, land prices became cheaper and it was difficult to sell their land. Thus, some women said that they had to think seriously about whether to buy farm land at that time.

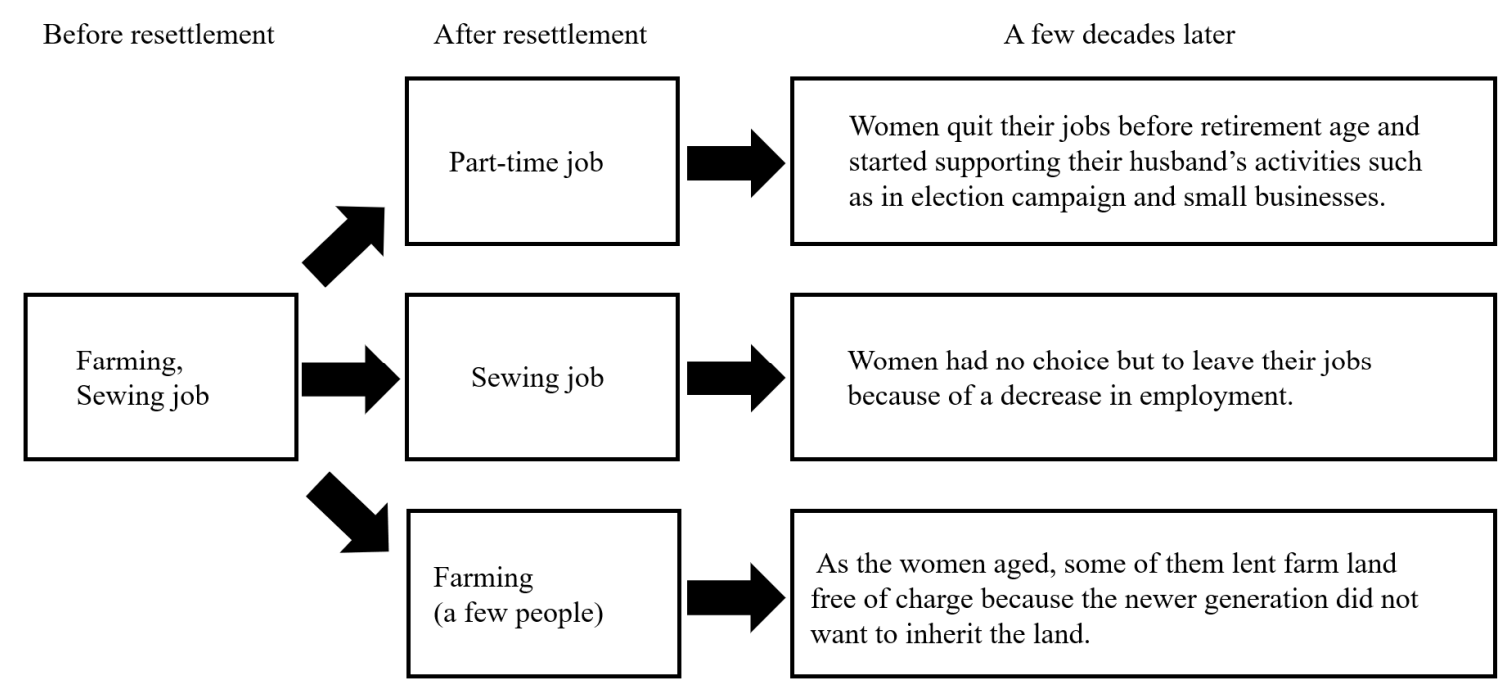

Figure 3. Changes of women's productive activities in the long run

\section{Evaluation of the IRR and PAR models}

\subsection{IRR Model}

Through analysis of the Tokuyama case, both the difficulties and effectiveness of the IRR model became clear. As for the difficulties, it was hard to explain the trivial risks, which mainly occurred in a developed country such as hesitation to state their opinions in meetings for resettlement or to insist on their common forest area while women are completely excluded from meetings in case of developing countries. The reason why the IRR model has difficulty in explaining these trivial risks is that this model was made based on some involuntary resettlement cases in developing countries. Therefore, this model is not useful to describe the same phenomena in a developed country. On the other hand, the IRR model is effective in describing gender issues in the context of dam resettlement. Fujikura and Nakayama (2015) evaluate some dam resettlement cases in Asian countries by the IRR model and the Tokuyama case was also analyzed. However, it was clear that some risks and good practices can be found in the Tokuyama case from the gender perspective, which were not pointed out in the previous research. Good practices include, for example, a system of job placement, and allowing both women and men to participate in meetings to facilitate livelihood reestablishment. 


\subsection{PAR Model}

Basically, the PAR model is used for disaster cases and is seldom used for dam resettlement. However, the result of this research proves that the PAR model is useful to explain factors connecting issues in involuntary displacement due to dam construction. The PAR model works well especially with gender issues because this model also explains the factors that arise from root causes, such as money management by men. In contrast to the effectiveness of the PAR model, no factors were explained by the category of unsafe conditions. However, there is a possibility that some factors connecting gender issues in developing countries can be categorized into unsafe conditions because the physical environment (such as a dangerous location) and the local economy (such as low-income levels) are completely different from the Japanese case.

\section{Acknowledgments}

This work was supported by JSPS KAKENHI Grant Number JP16H03320. The authors appreciate the great assistance of the Japan Water Agency in conducting the survey and are deeply grateful to resettled individuals who were willing to offer their precious time.

\section{References}

Aoki, R. (2018). Collection Development on Women's Earthquake Disaster Experiences and Support Activities in Japan. IFLA WLIC 2018 - Kuala Lumpur, Malaysia - Transform Libraries, Transform Societies in Session 207 - Women, Information and Libraries SIG and LGBTQ Users SIG.

Anonymous. (2018a). Interviews by the author with anonymous "dam brides" from the old Tokuyama village in a resettlement area. 17 September 2018.

Bari, S. (1992). "How Women Cope: Women in the Aftermath." In Hameeda Hossain et al. (Eds.), From Crisis to Development: Coping with Disasters in Bangladesh (pp. 55-58). Dhaka: University Press Ltd.

Blaikie, P., Cannon, T., Davis, I., \& Wisner, B. (2004). At risk: Natural hazards, people's vulnerability and disasters. London: Routledge.

Cernea, M. M., \& McDowell, C. (2000). Risks and reconstruction: Experiences of resettlers and refugees. Washington, D.C.: The World Bank.

Chowdhury, M. (2001). "Women's Technological Innovations and Adaptations for Disaster Mitigation: A Case Study of Charlands in Bangladesh.” DAW/ISDR Expert Group Meeting on "Environmental Management and the Mitigation of Natural Disasters: A Gender Perspective," Ankara, Turkey, November.

Fujihashi-mura [Fujihashi local office]. (1990). Tokuyama dam no kiroku [The history of Tokuyama dam]. Nagoya: Fujihashi-mura.

Fujikura, R., \& Nakayama, M. (2015). Resettlement policy in large development projects. London: Routledge. 
Gihuken chihou jichi kenkyuu senta [Local autonomy research center in Gihu prefecture]. (1988). Tokuyama damu. ijyuusha no sonogo [Displaced people by Tokuyama dam after resettlement]. Jichiken gihu zoukan, 2.

Hamamoto, A. (2001). Koukyoujigyo minaoshi to tachinoki itensha no seishinhigai-Gihuken - Tokuyama damu Keikaku no jirei yori [Reconsideration of public works and emotional distress for displaced people - in the case of Tokuyama dam]. Kankyoushakaigakukenkyu, 7.

Japan Dam Foundation. (2016). Damu nenkan [Dam yearbook]. Tokyo: Japan Dam Foundation.

Jehom, W. J. (2013). Reconstruction of post-resettlement gender relations: The Kenyah-Badeng of Sungai Asap, Sarawak, Malaysia. Asian Journal of Women's Studies, 19(2), 122-147. https://doi.org/10.1080/12259276.2013.11666151

Kabeer, Naila. (1999). Resource, Agency, and Achievement: Reflections on the Measurement of Women's Empowerment. Development and Change, 30(3), 435-464.

Kimura, K. (1997). Tamokuteki damu kaihatsu to Ibiya jyumin no henten (II) [Multipurpose dam construction and a change of Ibiya residents]. Mizushigen · Kankyo keikaku, 10, 60-66. https://doi.org/10.6012/jwei.1990.15

Kumar, S. P. (1987). The Mahaweli scheme and rural women in Sri Lanka. Women farmers and rural change in Asia: Towards equal access and participation. (220-253). Kuala Lumpur: Asia and Pacific Development Centre.

Nakayama, M., \& Matsumoto, K. (2016). From deep in the mountains: The Miboro and Tokuyama Dams in Japan. Asian Journal of Environment and Disaster Management, 7(4), 321-332.

Sikka, G. (2016). The case of missing toilets in Sardar Sarovar dam resettlement in Vadodara, Gujarat. GeoJournal, 81, 257-266. https://doi.org/10.1007/s10708-014-9617-z

Scudder, T. (2005). The Future of Large Dams: Dealing with Social, Environmental, Institutional and Political Costs. London: Earthscan.

Sugiura, M., \& Matsumoto, K. (2016). Involuntary resettlement with differing degrees of dependency on farmland: The Tokuyama dam resettlement in Japan. Asian Journal of Environment and Disaster Management, 7(4), 359-372.

Tan, Y., Hugo, G., \& Potter, L. (2005). Rural women, displacement and the Three Gorges Project. Development and Change, 311-734. https://doi.org/10.1111/j.0012-155X.2005.00431.x

Tanaka, Y., Osawa, M., \& Ito, R. (2001). Kaihatsu to jenda enpawamento no kokusaikyoryoku [Development and international cooperation of gender empowerment]. Tokyo: Kokusaikyoryoku shuppankai.

World Bank, Environmentally Sustainable Department (ESD). (1996). Resettlement and Development, The Bank-wide Review of Projects involving Involuntary Resettlement 1986-93. 
Washington, D.C.: World Bank.

World Bank. (2012). Involuntary resettlement portfolio review phase I inventory of bank-financed projects triggering the involuntary resettlement policy (1990-2010). Washington, D.C.: World Bank.

Wisner, B., Gaillard, J. C., \& Kelman, I. (2012). Framing disaster: theories and stories seeking to understand hazards, vulnerability and risk. Handbook of hazards and disaster risk reduction. London: Routledge.

Yamazawa, S., Moriya, K., \& Nakayama, M. (2018). Gender Issues in Involuntary Resettlement due to Dam Construction: "Dam Brides" and the Tokuyama Dam in Japan. International Journal of Social Science Studies, 6(4), 13-19. https:/doi.org/10.11114/ijsss.v6i4.2954

\section{Copyright Disclaimer}

Copyright for this article is retained by the author(s), with first publication rights granted to the journal.

This is an open-access article distributed under the terms and conditions of the Creative Commons Attribution license (http://creativecommons.org/licenses/by/4.0/). 